\title{
Conventional and Ultra-fast Analysis Exposing the Harvest Date Impact on Lebanese Olive Oil: The Soury Variety
}

\author{
Omar H. Dib ${ }^{1,2}$, Christophe B. Y. Cordella ${ }^{1,4}$, Rita Yaacoub ${ }^{2}$, Hussein Dib $^{2}$, Nathalie Locquet $^{1}$, Luc Eveleigh $^{3} \&$ \\ Ali Bassal $^{2}$ \\ ${ }^{1}$ UMR PNCA, AgroParisTech, INRA, Université Paris-Saclay, Paris, 75005, France \\ ${ }^{2}$ Department of Food Science and Technology, Lebanese University, Beirut, Dekweneh, 1003, Lebanon \\ ${ }^{3}$ Ingénierie Procédés Aliments, INRA, AgroParisTech, Université Paris-Saclay, Massy, 91300, France \\ ${ }^{4} \mathrm{C}^{2} \mathrm{~B}$ research group - Chimiométrie pour la Caractérisation de Biomarqueurs, France \\ Correspondence: Christophe B. Y. Cordella, UMR PNCA, AgroParisTech, INRA, Université Paris-Saclay, Paris, \\ 75005, France. Tel: 33-166-641-6900. E-mail: christophe.cordella@inrae.fr
}

$\begin{aligned} & \text { Received: October 22, } 2020 \quad \text { Accepted: November 28, } 2020 \quad \text { Online Published: January 10, } 2021 \\ & \text { doi:10.5539/jfr.v10n1p39 }\end{aligned} \quad$ URL: https://doi.org/10.5539/jfr.v10n1p39

\begin{abstract}
The impact of harvest period on the quality parameters, polyphenols, fatty acids, sterols, and volatile compounds of Lebanese olive oil from the Soury variety was investigated in this study. Two groups of olive oil were compared, each with a specific harvest date. HD1 was harvested in October, whereas HD2 was picked in November. The analysis of both olive oil categories showed that HD2 witnessed a significant increase in all quality parameters except $\mathrm{K} 270$ and a decrease in total polyphenol content from $138 \mathrm{mg} / \mathrm{mL}$ to $44 \mathrm{mg} / \mathrm{mL}$. Oleic and linoleic acids had an inverse relation, where the former decreased and the latter increased with the harvest date's advancement. Palmitic acid in both groups was higher than the standards set for extra virgin olive oil. The relative amount of $\beta$-Sitosterol was mainly found to decrease, while those of stigmasterol, $\Delta^{5,24}$-stigmastadienol, $\Delta^{7}$-stigmastenol, and $\Delta^{7}$-avenasterol increased with delaying harvest time. As for the volatile compounds, principle component analysis was used on the flash GC data to differentiate HD1 from HD2. Ethanol was found mostly characterizing HD2, whereas HD1 was influenced by 1-hexanol and (E,E)-2,4-decadienal. It can be concluded that the Soury variety should be harvested early, and a delay would result in the declassification of Lebanese olive oil quality from extra virgin to virgin olive oil.
\end{abstract}

Keywords: chemical characterization, harvest date, Lebanese olive oil, soury variety

\section{Introduction}

Lebanon is home to the oldest olive trees dating back centuries (at least 1,500 years). It has been distinguished for its trade-in crop products, including olive and olive oil along the Mediterranean Basin (Thalman, 2000; Beayno et al., 2002; Mahfoud, 2007). Lebanon produces around 24,000 tons of olive oil. For the last six years, the production ranged between 16,500 $\mathrm{t}$ and 25,000t (International Olive Council [IOC], 2018). This fluctuation in production can be induced by several agronomical (El Antari, Hilal et al., 2000, Stefanoudaki, Chartzoulakis et al., 2001) and technological factors (García et al., 1996; Koutsaftakis et al., 1999). Among these factors, an agronomical factor that is recognized as the one having the most detrimental effect on olive oil chemical composition is the harvest date (De La Torre et al., 1985; Fiorino \& Nizzi, 1991; Koutsaftakis et al., 2000).

As olive fruit matures, the color of the fruit shifts from green at the start of the harvest period to small reddish-green spots to purple and lastly to black at the end of the harvest period (Motilva \& Romero, 2010). Each stage imparts its chemical variations on the level of macro and minor components of olive oil, such as triglycerides, fatty acids, polyphenols, sterols, and chlorophylls, which in turn have an impact on olive oil quality (Gargouri et al., 2016). Besides, these variations influence not only the quality but also the nutritional, the organoleptic characteristics, and the oxidative stability of olive oil (Maaitah et al., 2009). However, the variation based on fruit maturity depends also on the cultivar in the study.

For instance, Issaoui et al., (2010) related the increase of polyunsaturated and the decrease of monounsaturated fatty acid to fruit maturation. In other cases, the level of monounsaturated fatty acids increased, along with the level of saturated and polyunsaturated fatty acids, as in Barnea variety. As for the Soury variety, Lodolini et al., 
(2017) showed that the delay of harvest has a detrimental effect on olive oil quality. As it ripens, oleic content declines, and linoleic increases, quality indices, mostly free fatty acids, are negatively affected, while polyphenol levels and oxidative stability drop sharply. Also, it has been reported that the sterol content decreases sharply from $2850 \mathrm{~g} / \mathrm{kg}$ to $1644 \mathrm{~g} / \mathrm{kg}$ (Noorali et al., 2014). Moreover, fruit maturation has also been shown to affect olive oil quality parameters such as free fatty acids, peroxide value, specific UV absorbances, and volatile compounds (Famiani et al., 2002; Lazzez et al., 2008; Mailer et al., 2010; Varzakas et al., 2010; Dag et al., 2011; Gomez et al., 2011).

Because the macro and minor compounds of the Lebanese olive oil have not been studied extensively, we are interested in identifying some minor and macro components characterizing the Soury variety and studying the harvest date's impact on their evolution. Also, this study stresses the volatiles as a research gap in Lebanese olive oil.

\section{Methodology}

\subsection{Sampling}

Sixty-three olive oil samples of Soury variety were used in this study. The samples were divided into two groups (HD1 and HD2) according to their harvest date.

HD1 includes 21 extra virgin olive oil samples (EVOO), each extracted from $5 \mathrm{~kg}$ of healthy Soury olive fruits picked from mid of October till the first week of November. The color of the olive fruits of this group was green with purple dots. Oil samples were obtained by cold extraction using an Abencor analyzer (Mc2 Ingenieria y Sistemas, Seville, Spain) with a hammer mill $\left(5.5 \mathrm{~mm}\right.$ sieve), a mixer $\left(50 \mathrm{rpm}\right.$ for $30 \mathrm{mins}$ at $\left.28^{\circ} \mathrm{C}\right)$, and a centrifuge (3500 rpm for 2 mins). All oil samples were stored in glass bottles at $4^{\circ} \mathrm{C}$ without headspace till analysis.

HD2 is composed of 42 virgin olive oil (VOO) samples $(500 \mathrm{~mL})$ collected from Lebanese olive farmers. The olive fruits were harvested from mid of November till the end of November. The color of the olive fruits of this group was purple to black.

\subsection{Quality Parameters}

The determination of olive oil quality indices, such as acidity (calculated as oleic acid), peroxide value (PV), and UV spectrophotometric indices (K232, K270), was carried out according to the European Union Commission Regulation EEC No 2568/91 (European Union Commission [EEC], 2013).

\subsection{Total Polyphenols}

The analysis of total polyphenol content was carried out based on Montedoro et al., (1992). The phenols were isolated from oil in hexane by double extraction with methanol-water $(60: 40, \mathrm{v} / \mathrm{v})$. Total polyphenols were determined by a UV spectrophotometer (Hitachi U-2900, Spectrophotometer, Japan) at $765 \mathrm{~nm}$ using a Folin-Ciocalteu reagent. Caffeic acid standard solutions were used as a means of method calibration $\left(\mathrm{R}^{2}=\right.$ 0.9995).

\subsection{Fatty Acids}

The fatty acid profile of olive oil was determined by gas chromatography (GC) after methyl esterification of the acids, according to the International Olive Council (IOC) method COI/T.20/Doc. No 33 (IOC, 2017). Chromatographic analysis was performed using Shimadzu GC-2025 (Kyoto, Japan) equipped with a capillary column SP-2380 (30 m $\times 0.32 \mathrm{~mm}$ i.d. x $0.20 \mu \mathrm{m}$ film thickness; Supelco, Bellefonte, PA, USA) and an FID detector. Injector and detector temperatures were held at $230^{\circ} \mathrm{C}$ and $240^{\circ} \mathrm{C}$, respectively. The injection volume into a split GC port was $1 \mu \mathrm{L}$, and a split injection mode (1/100) was used. Helium was employed as the carrier gas at a flow rate of $1 \mathrm{~mL} / \mathrm{min}$. The following oven temperature program was used: initial temperature of $165^{\circ} \mathrm{C}$ held for $10 \mathrm{~min}$, ramped at $1.5^{\circ} \mathrm{C} \mathrm{min}^{-1}$ up to $200^{\circ} \mathrm{C}$. Fatty acids were identified by comparing the retention time of experimental peaks with those obtained by the standard external mixture.

\subsection{Sterols}

The sterols of olive oil were extracted according to the International Olive Council (IOC, 2013). 5g of olive oil were introduced to a $250 \mathrm{~mL}$ flask, already containing $\alpha$-cholestanol solution (internal standard solution), and saponified with $2 \mathrm{~N}$ ethanolic $2 \mathrm{M}$ potassium hydroxide solution. After boiling the solution, $100 \mathrm{~mL}$ of distilled water was added, and three extractions of the same unsaponifiable fraction were carried out using diethyl ether $(80 \mathrm{ml}, 70 \mathrm{ml}, 70 \mathrm{ml})$. The extracts were then washed with water $(50 \mathrm{~mL})$ until the wash water no longer gives a pink color upon the addition of phenolphthalein solution. The extracts were filtered on anhydrous sodium sulfate, and the filtered solvent was evaporated by distillation in a rotary evaporator at $30{ }^{\circ} \mathrm{C}$ under vacuum. 
Separation of the sterol and triterpene dialcohols fraction (erythrodiol + uvaol). 5\% solution of the unsaponifiable was prepared in chloroform and using the $100 \mu \mathrm{L}$ microsyringe, $0.3 \mathrm{~mL}$ of the solution was disposed on a narrow and uniform streak on the lower end $(2 \mathrm{~cm})$ of the TLC plate. The plate was then placed in the prepared developing chamber and allowed eluting until the solvent reaches approximately $1 \mathrm{~cm}$ from the plate's upper edge. The plate was then sprayed with $0.2 \%$ 2,7-dichlorofluorescein to identify the sterol area. The sterol band was then identified using UV light, and the silica gel on the marked area was scraped off using a metal spatula, dissolved in chloroform and diethyl ether, and evaporated to dryness. The obtained sterols and triterpene dialcohols were transformed into trimethylsilyl ethers by adding a 9:3:1 (v/v/v) mixture of pyridine/hexamethyldisilazane/trimethylchlorosilane (in the ratio of $50 \mu \mathrm{L}$ for every milligram of sterols).

GC-MS Analysis. The mixture was analyzed using ITQ 900 GC-MS (Trace 1310 GC, Thermo Scientific, USA) system with a quadrupole ion trap mass analyzer supplied with split/splitless injection autosampler (Thermo Scientific AI/AS 1310). A DB-5 type 5\% phenyl-95\% methyl polysiloxane fused- silica capillary column, DB-5MS (30 m x $0.25 \mathrm{~mm} \times 0.25 \mathrm{um}$, Agilent Technologies, USA), non-polar, low bleed, and with high-temperature limits (up to $350{ }^{\circ} \mathrm{C}$ ), was chosen for testing sterol samples. The helium carrier gas was used at a flow rate of $1.2 \mathrm{~mL} / \mathrm{min}$. The oven temperature was initially set at $100{ }^{\circ} \mathrm{C}$ for 2 mins, then gradually raised to $267{ }^{\circ} \mathrm{C}$ at $40{ }^{\circ} \mathrm{C} / \mathrm{min}$ rate and held for 40 mins. The injection was spitless at $280{ }^{\circ} \mathrm{C}$. The ion source temperature was set at $230{ }^{\circ} \mathrm{C}$, and the transfer line was at $290{ }^{\circ} \mathrm{C}$. No calibration ranges were needed, as all samples have an internal standard ( $\alpha$-cholestanol). Sterols were identified by comparing the retention time of the obtained peaks with the retention time of IOC reference peaks (similar experimental conditions were executed).

Sterol relative amounts (\%) were expressed with respect to the internal standard and proportions of total sterols. The apparent $\beta$-Sitosterol was calculated as the sum of $\beta$-sitosterol, $\Delta^{5}$-avenasterol, clerosterol, sitostanol, and $\Delta^{5,24}$-stigmastadienol.

\subsection{Volatile Compounds}

Volatile compounds of olive oil samples were analyzed using FGC E-nose Heracles II (AlphaMos, Toulouse, France), equipped with two columns: a non-polar column (MXT5: 5\% diphenyl, 95\% methylpolysiloxane, $10 \mathrm{~m}$ length and $180 \mathrm{~mm}$ diameter) and a slightly polar column (MXT1701: 14\% cyanopropylphenyl, 86\% methylpolysiloxane, $10 \mathrm{~m}$ length and $180 \mathrm{~mm}$ diameter).

$500 \mu \mathrm{L}$ of olive oil was placed in a $20 \mathrm{~mL}$ vial and sealed with a cap. The vial present in Heracles' auto-samples was then transferred to a shaker oven for $15 \mathrm{~min}$ at $80^{\circ} \mathrm{C}$, shaken at $500 \mathrm{rpm}$. Next, a syringe pierced the cap's silicone septum and sampled $5 \mathrm{~mL}$ of the headspace, which were then adsorbed on a CARBOWAX trap, maintained at $30{ }^{\circ} \mathrm{C}$ for $36 \mathrm{~s}$, while the carrier gas $\left(\mathrm{H}_{2}\right)$ flowed through it to concentrate the analytes by removing excess air and moisture. The analytes were then desorbed by increasing the trap's temperature to $240{ }^{\circ} \mathrm{C}$ in $90 \mathrm{~s}$, and the sample was injected. The thermal program started at $40{ }^{\circ} \mathrm{C}$ (held for $2 \mathrm{~s}$ ) and increased to $280{ }^{\circ} \mathrm{C}$ at $4{ }^{\circ} \mathrm{C}$ $/ \mathrm{s}$. The final temperature was held for $21 \mathrm{~s}$. The total separation time was $100 \mathrm{~s}$. At the end of each column, an FID detector was placed, and the acquired signal was digitalized every $0.01 \mathrm{~s}$.

For calibration, an alkane solution (from n-hexane to n-hexadecane) was used to convert retention time in Kovats indices and identify the volatile compounds using specific software (AroChemBase, Alpha MOS, France).

\subsection{Statistical analysis}

Statistical analysis was performed using Matlab version R2015b (The Mathworks Inc., MA, USA) using the SAISIR package (Cordella \& Bertrand, 2013), and the ANOVA results are presented as means \pm standard deviation. Tukey's test was used to establish the significance of difference, at a $5 \%$ level among means, for each parameter taking harvest date into account. A model based on principal component analysis (PCA) was developed to study the harvest period's influence on volatile compounds.

\section{Results and Discussion}

\subsection{Quality Parameters and Total Polyphenol Content}

The results illustrated in Table 1 show the fundamental differences in the analyzed physicochemical parameters between olive fruits harvested in October and those in November. The quality parameters of olive oils (acidity and peroxide value) were found to be significantly different during the two notable harvest dates in Lebanon. On average, acidity values were $0.31 \%$ and $1.21 \%$ for HD1 and HD2, respectively, exceeding the limit established by the International Olive Council (IOC) for oils to be considered extra virgin $(0.8 \%)$ for the latter. The observed increase in November corroborates with other authors (Youssef et al., 2010; Fuentes et al., 2013). It can be explained by the increase in lipolytic activity as the olives become more sensitive to mechanical damage and pathogenic infections (Anastasopoulos et al., 2011). 
Peroxide value of olive oils harvested in November showed a significant increase of about $9.34 \mathrm{meq} \mathrm{O}_{2} / \mathrm{kg}$ compared to those picked in October. However, the delay in harvesting olive fruits should show a lower peroxide level due to the decrease in lipoxygenase activity (Salvador et al., 2001; Alowaiesh et al., 2016). The significant increase observed in HD2 was unexpected and required further examination. Although an increase was noticed, all olive oils presented peroxide values that did not exceed the maximum acceptable limit for their classification as extra virgin olive oils $\left(<20 \mathrm{mEq} \mathrm{O}_{2} / \mathrm{kg}\right)$.

K232 and K270 are the markers of olive oil alteration. K232 is in direct relation with poly-unsaturated fatty acids and peroxide value, whereas K270 relates to aldehyde and ketone substances. As the harvest date is delayed, the value of K232 increases, while K270 decreases (Hamidoghli et al., 2008). However, a study by Bengana et al., (2013) showed an inverse pattern as olive fruit ripens, while in other studies, both indicators decreased with maturity and depended on olive cultivar and harvest date. In our case, a decrease in K232 and an increase in K270 were observed for the studied Soury variety shown in Table 1. All studied samples had K232 and K270 values consistent with IOC's limit for extra virgin olive oil.

Phenolic compounds are of great organoleptic and nutritional interest. They are associated with the taste and the oil's stability due to their antioxidant properties (Maga, 1978; Nergiz \& Ünal, 1991). As the harvest time is delayed, oleuropein, the main bitterness-producing component in olives, progressively decreases (Amiot et al., 1986; Amiot et al., 1990). This was confirmed by our results (Table 1), as the total polyphenol content observed for HD1 was significantly higher than that for HD2. These findings suggest a decline in the oil's oxidative stability as harvesting is delayed (Gutiérrez et al., 1999; Trentacoste et al., 2020). The observed decline as ripening advances may be attributed to the polyphenol oxidase that dominates the final stage of the ripening process and to the fusion of the phenolic acids into the cell walls as a fruit defensive mechanism against pathogens (Amira et al., 2012; Rodríguez et al., 2016).

Table 1. Quality parameters and total polyphenol content for both groups (HD1 and HD2)

\begin{tabular}{llllll}
\hline & Acidity $\dagger(\mathrm{g} / 100 \mathrm{~g})$ & $\mathrm{PV} \pm\left(\mathrm{meq} \mathrm{O}_{2} / \mathrm{kg}\right)$ & $\mathrm{K} 232$ & $\mathrm{~K} 270$ & Total polyphenols $(\mathrm{mg} / \mathrm{mL})$ \\
\hline $\mathrm{HD} 1$ & $0.31 \pm 0.06 \mathrm{~b}$ & $3.10 \pm 1.06 \mathrm{~b}$ & $1.81 \pm 0.22 \mathrm{~b}$ & $0.17 \pm 0.04 \mathrm{a}$ & $138.31 \pm 43.44 \mathrm{a}$ \\
$\mathrm{HD} 2$ & $1.21 \pm 0.37 \mathrm{a}$ & $12.44 \pm 4.54 \mathrm{a}$ & $2.04 \pm 0.30 \mathrm{a}$ & $0.15 \pm 0.04 \mathrm{~b}$ & $44.08 \pm 21.34 \mathrm{~b}$ \\
EVOO* & $\leq 0.8$ & $\leq 20$ & $\leq 2.5$ & $\leq 0.22$ & - \\
\hline
\end{tabular}

All determinations were carried out in duplicate. Different letters within the same column show significant differences (Tukey's test, $\mathrm{p} \leq 0.05$ ). $\dagger$ Calculated as oleic acid; $\$$ Peroxide value; *Standards of IOC for extra virgin olive oil (EVOO)

\subsection{Fatty Acid Composition}

Fatty acids are the major constituents of olive oil and are an essential factor in determining the authenticity and the quality of olive oil (Essiari et al., 2014). Changes in the fatty acid composition are presented in Table2. The major fatty acids included in this study are palmitic, oleic, and linoleic acid. The minor fatty acids are palmitoleic, stearic, linolenic.

Among fatty acids, oleic acid was high in HD1 and showed a slight decrease in HD2. On the contrary, linoleic acid concentration significantly increased from $9.09 \%$ to $11.09 \%$ (El Qarnifa et al., 2019). This increase may be related to the activity of oleate desaturase. Oleate desaturase is an enzyme responsible for the desaturation of Oleoyl-ACP (precursor of longer-chain unsaturated fatty acids) into linoleate-ACP, which might be the reason behind the notable difference in the oleic and linoleic concentrations between these two groups. This enzyme has been extensively discussed in seed oils; however, the information regarding the enzyme activity in olive oil is still limited (Hernandez et al., 2011). Another factor for the existing difference between HD1 and HD2 is the continuing biosynthesis of triglycerides as the harvesting date is delayed (Flamini, 2010; Guiterrez, 1999). Lodolini et al. (2017) have also reported that the Soury variety should be harvested early. The postponement of olive fruit harvest has a detrimental effect on olive oil's fatty acid composition, mainly oleic and linoleic content.

All fatty acids were within the acceptable limit for their classification as extra virgin olive oils except for palmitic acid in both HD1 and HD2, which may be a characteristic of the Soury variety and, further investigation is required. 
Table 2. Mean values \pm standard deviation of fatty acids (\%) composition of Lebanese olive oil at two harvest dates (October and November)

\begin{tabular}{lllllll}
\hline & Palmitic & Palmitoleic & Stearic & Oleic & Linoleic & Linolenic \\
\hline HD1 & $10.71 \pm 1.37 \mathrm{a}$ & $0.50 \pm 0.17 \mathrm{a}$ & $3.70 \pm 0.71 \mathrm{a}$ & $73.79 \pm 2.20 \mathrm{a}$ & $9.09 \pm 1.53 \mathrm{~b}$ & $0.59 \pm 0.07 \mathrm{a}$ \\
HD2 & $11.28 \pm 1.3 \mathrm{a}$ & $0.58 \pm 0.17 \mathrm{a}$ & $4.01 \pm 0.5 \mathrm{a}$ & $70.86 \pm 2.34 \mathrm{~b}$ & $11.09 \pm 1.45 \mathrm{a}$ & $0.63 \pm 0.08 \mathrm{a}$ \\
EVOO* & $2.0-7.5$ & $0.3-3.5$ & $0.5-5$ & $55-83$ & $3.5-21$ & $\leq 1$ \\
\hline
\end{tabular}

All determinations were carried out in duplicate. Different letters within the same column show significant differences (Tukey's test, $\mathrm{p} \leq 0.05$ ). *Standards of IOC for extra virgin olive oil (EVOO).

\subsection{Sterol Content}

The sterol content of olive oil samples for the two harvesting periods is recorded in Table3. The sterols with the highest amounts were $\beta$-sitosterol, $\Delta^{5}$-avenasterol, and campesterol representing more than $90 \%$ of total sterol content, whereas other sterols like stigmasterol, clerosterol, sitostanol, $\Delta^{5,24}$-stigmastadienol, $\Delta^{7}$-stigmastenol, $\Delta^{7}$-avenasterol and two triterpene dialcohols (erythrodiol and uvaol) were within small amounts.

The total sterol content of HD2 exceeded the $1000 \mathrm{mg} / \mathrm{kg}$ threshold for HD2, as shown in Table 3. This result is in agreement with Lukić et al., (2013), who stated that the levels of sterols continue to increase until the olive fruit is ripened. Apparent $\beta$-Sitosterol of both groups was higher than $93 \%$ as determined by the EU regulations.

The mean relative amount of $\beta$-sitosterol was mainly found to decrease, while those of stigmasterol, $\Delta^{5,24}$-stigmastadienol, $\Delta^{7}$-stigmastenol, and $\Delta^{7}$-avenasterol increased as per previous studies (Camera et al., 1975; Koutsaftakis et al., 1999; Salvador et al., 2001; Vekiari et al., 2010). The percentage of clerosterol was relatively stable, which agrees with the findings of Lazzez et al., (2008). The same was observed for campesterol, sitostanol, $\Delta^{5}$-avenasterol, and erythrodiol + uvaol.

Concerning the amount of $\beta$-Sitosterol, representing the most copious compound in the sterolic fraction, the maximum relative amount (about 91.49\%) was observed for HD1, whereas the lowest content was about $89.67 \%$ for HD2. The $\Delta 5$-avenasterol, the second most abundant sterolic compound, reached $4.47 \%$ during the maturity process (HD2). Several authors had found a negative correlation between $\beta$-sitosterol content, $\Delta^{5}$-avenasterol and $\Delta^{7}$-avenasterol in different varieties (Koutsaftakis et al., 1999; Fernández-Cuesta et al., 2013; Lukić et al., 2013; Yorulmaz et al., 2013; Noorali et al., 2014). They stated that $\beta$-Sitosterol is minimum and $\Delta^{5}$-avenasterol and $\Delta^{7}$-avenasterol is maximum when olives are obtained at their optimum maturation stage. In this study, a decrease in $\beta$-Sitosterol content, and an increase in $\Delta^{7}$-avenasterol was observed. This complements the results obtained by the latter authors. However, $\Delta^{5}$-avenasterol content showed no significant differences between HD1 and HD2 in disagreement with the same research.

The third sterolic compound, the campesterol, reached the highest of $2.10 \%$ for HD2. Our samples presented low levels of this sterol (less than the 4\% limit value), and no significant difference was observed between HD1 and HD2. As for the stigmasterol, the authors found its high content to be an indicator for lower olive oil/olive fruit quality (JM et al., 1996; Koutsaftakis et al., 1999; Gutiérrez and Fernández, 2002; Temime et al., 2008). This is in agreement with the results shown in Table 1 and Table 3. HD2 (VOO) has a lower quality than HD1 (EVOO) and thus higher stigmasterol content. The campesterol/stigmasterol ratio, another parameter classified as a quality index of olive oils (Koutsaftakis et al., 1999), also decreased as the harvest date is delayed. The $\Delta^{7}$-Stigmastenol and $\Delta^{5,24}$-stigmastadienol witnessed a significant increase in HD2. The primary factor of this increase is the delay in the harvest. Erythrodiol + uvaol content in all the oil samples studied was below the limit of $4.5 \%$ and was not affected by the postponement of harvest time. 
Table 3. Relative amounts (\%) of sterols and triterpene diols determined in olive oils at two harvest dates (October and November)

\begin{tabular}{llll}
\hline & HD1 & HD2 & IOC standards \\
\hline Relative amount (\%) & $0.05 \mathrm{a} \pm 0.02 \mathrm{a}$ & $0.04 \pm 0.02 \mathrm{a}$ & $\leq 0.5$ \\
Cholesterol & $2.06 \pm 0.83 \mathrm{a}$ & $2.10 \pm 0.74 \mathrm{a}$ & $\leq 4$ \\
Campesterol & $0.44 \pm 0.29 \mathrm{~b}$ & $0.72 \pm 0.55 \mathrm{a}$ & $<$ campesterol \\
Stigmasterol & $5.20 \pm 1.29 \mathrm{a}$ & $3.56 \pm 1.52 \mathrm{~b}$ & \\
Campesterol/Stigmasterol ratio & $0.69 \pm 0.24 \mathrm{a}$ & $0.71 \pm 0.20 \mathrm{a}$ & \\
Clerosterol & $91.49 \pm 3.51 \mathrm{a}$ & $89.67 \pm 3.33 \mathrm{~b}$ & \\
$\beta$-Sitosterol & $0.15 \pm 0.09 \mathrm{a}$ & $0.15 \pm 0.13 \mathrm{a}$ & \\
Sitostanol & $3.99 \pm 2.04 \mathrm{a}$ & $4.47 \pm 2.21 \mathrm{a}$ & \\
$\Delta^{5}$-Avenasterol & $0.35 \pm 0.20 \mathrm{~b}$ & $0.50 \pm 0.25 \mathrm{a}$ & \\
$\Delta^{5,24}$-Stigmastadienol & $0.35 \pm 0.20 \mathrm{~b}$ & $0.69 \pm 0.38 \mathrm{a}$ & $\leq 0.5$ \\
$\Delta^{7}$-Stigmastenol & $0.49 \pm 0.37 \mathrm{~b}$ & $0.71 \pm 0.40 \mathrm{a}$ & \\
$\Delta^{7}$-Avenasterol & $96.59 \pm 1.48 \mathrm{a}$ & $95.52 \pm 1.69 \mathrm{a}$ & $\geq 93$ \\
Apparent $\beta$-Sitosterol & $2.55 \pm 1.21 \mathrm{a}$ & $2.18 \pm 1.07 \mathrm{a}$ & $4.5 \%$ \\
Erythrodiol + Uvaol & $894.40 \pm 211.84 \mathrm{~b}$ & $1077.48 \pm 327.7 \mathrm{a}$ & $\geq 1000$ \\
Total sterols (mg/Kg) & &
\end{tabular}

Results are denoted as mean value \pm standard deviation of two replicates. Different letters in the same row show significant differences (Tukey's test, $\mathrm{p} \leq 0.05$ ).

\subsection{Volatile Compounds}

FGC was carried out to detect the volatile compounds that may arise due to the olive fruit harvest delay, particularly the Soury variety.

A PCA model with 21 olive oil samples composing the HD1 group and 42 olive oil samples, belonging to the group HD2 and 10201 data points (constituting the flash GC chromatogram), i.e., an initial X data matrix of $63 \mathrm{x}$ 10201 was conditioned. The initial chromatograms were corrected for misalignments before any further analysis using correlation optimized warping (COW) (Nielsen et al., 1998). Data were then normalized using standard normal variate (SNV) (Zeaiter \& Rutledge, 2009).

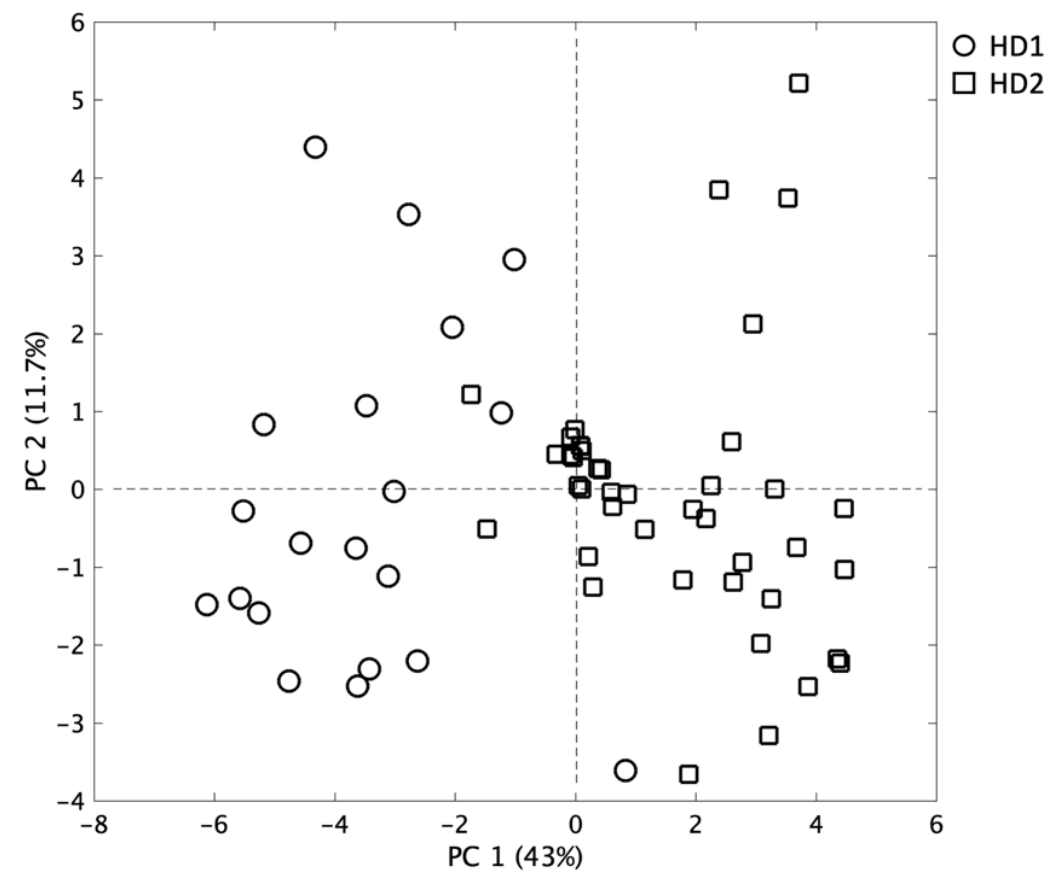

Figure 1. PCA scatter plots of the two groups (HD1 and HD2) obtained by analyzing the flash-GC chromatogram 


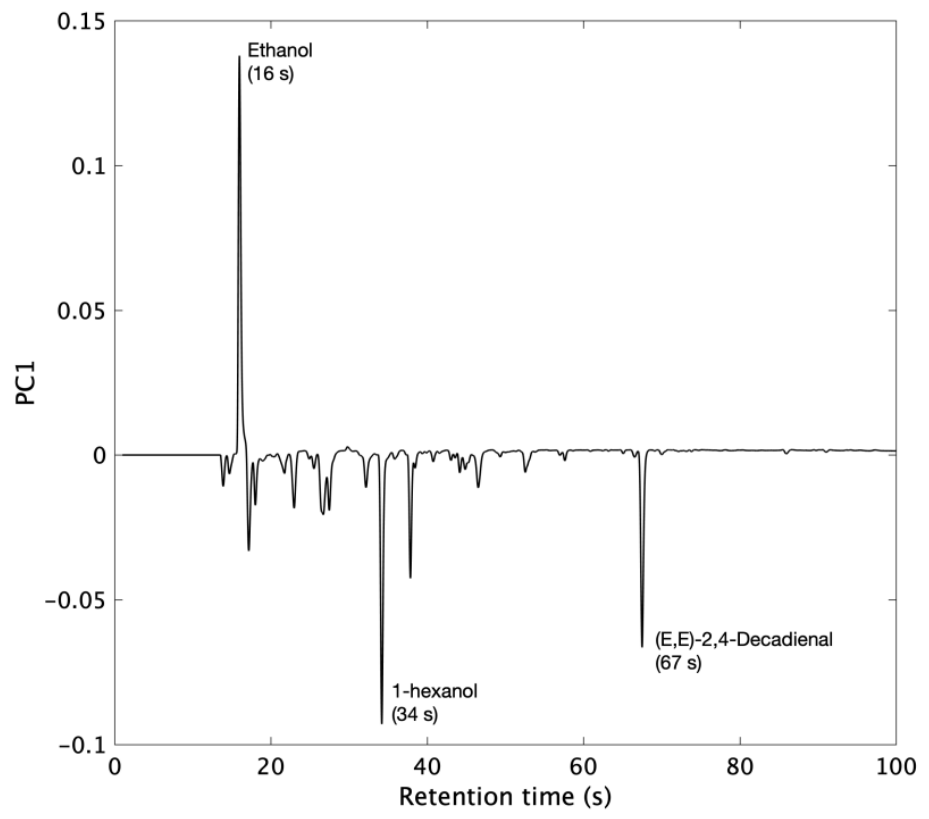

Figure 2. Loading plot showing the peaks differentiating HD1 from HD2

Six principal components (PCs) were extracted, covering $86.5 \%$ of the total variance, where the first two components accounted for $54.7 \%$ of the variability in the data set. The first two PCs were plotted, showing a good differentiation between HD1 and HD2 (Figure 1). PC1 clearly shows the discrimination between HD1 and HD2. One-way ANOVA was also conducted on PC1 scores as an extra measure of certainty for the PCA results. A significant difference was also noted between HD1 and HD2 $(\mathrm{p} \leq 0.05)$, as shown in Figure 3. In comparing HD1 and HD2, three peaks are identified as the determinant factor in separating the two latter groups (Figure 2). The first peak is ethanol, belonging to one of the major volatile olive oil compounds, i.e., alcohol. The Kovats indices (KI) for this peak were identified through AroChembase software and compared with KI available in the literature (Table 4).

Table 4. Olive oil volatile compounds based on Kovats indices (KI) calculated on retention time (RT) for two columns

\begin{tabular}{|c|c|c|c|c|c|}
\hline $\begin{array}{l}\text { RT DB5 } \\
(\mathrm{sec})\end{array}$ & $\begin{array}{l}\text { RT DB1701 } \\
(\mathrm{sec})\end{array}$ & $\begin{array}{l}\text { KI } \\
\text { (DB5) }\end{array}$ & $\begin{array}{l}\text { KI } \\
\text { (DB1701) }\end{array}$ & $\begin{array}{l}\text { Possible chemical } \\
\text { candidate }\end{array}$ & Reference \\
\hline 16 & 39 & 440 & 883 & Ethanol & $\begin{array}{l}\text { (Ivanova-Petropulos et al., 2015) } \\
\text { (Silva et al., 2012) }\end{array}$ \\
\hline 34 & 59 & 835 & 1340 & 1-hexanol & $\begin{array}{l}\text { (Silva et al.. 2012) } \\
\text { (Brkić Bubola et al., 2012) } \\
\text { (Ben Mansour et al., 2017) } \\
\text { (Pouliarekou et al., 2011) }\end{array}$ \\
\hline 67 & 92 & 1320 & 1730 & (E,E)-2,4 -Decadienal & $\begin{array}{l}\text { (Silva et al.. 2012) } \\
\text { (Kesen et al., 2013) } \\
\text { (Reiners and Grosch, 1998) }\end{array}$ \\
\hline
\end{tabular}




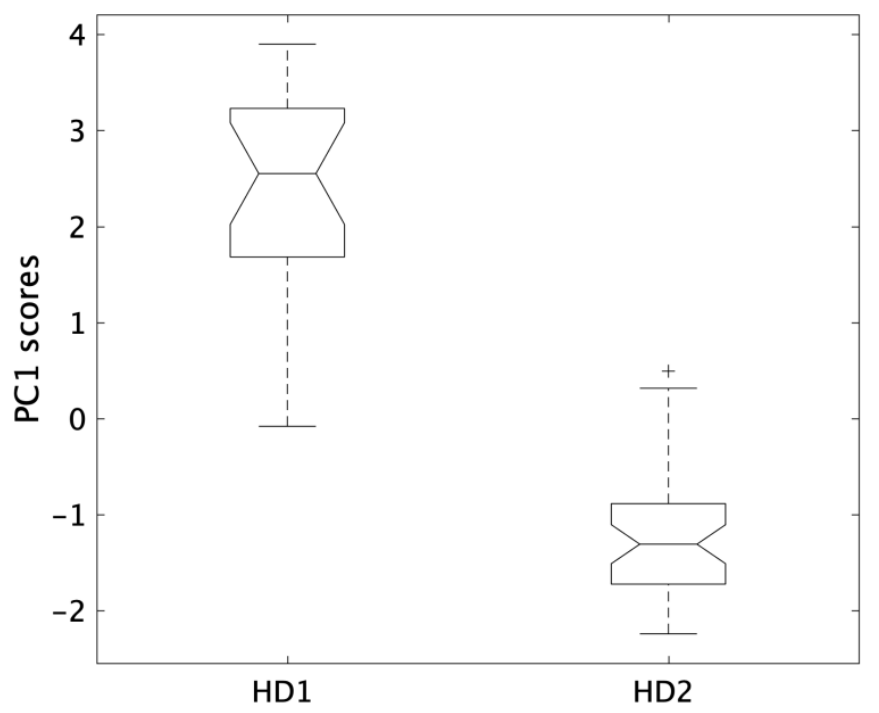

Figure 3. Boxplot showing the discrimination of both groups HD1 and HD2 ( $\leq \leq 0.05)$

Ethanol is a major component, which is related to the fermentation activity occurring before olive oil extraction (Beltrán et al., 2015), and it is responsible for the sensory descriptor "Alcohol" (Morales et al., 2005). The possible source of ethanol can be from the olive fruit itself. Beltrán et al., (2015) showed that ethanol content increase during the ripening process. This increase is directed by alcohol dehydrogenase activity, where its levels were high due to advanced stages of maturation. The remaining two high-intensity peaks, mostly characterizing HD1, are 1-hexanol and (E, E)-2,4-decadienal. 1-hexanol appears in HD1 as a sign of unripe olives (Aparicio and Morales, 1998). It is known that at a later harvest date (HD2), the aromatics, like 1-hexanol, describing the term "fruity-grassy," are lower while other negative aromatic notes increase like ethanol (Salvador et al., 2001). As for (E, E)-2,4-decadienal, its presence in HD1 may be due to the long incubation period of olive oil just before injection into the FGC, which led to such a volatile compound. This peak is also present in HD2; however, its presence is hidden by the ethanol high-intensity peak (Figure 4).

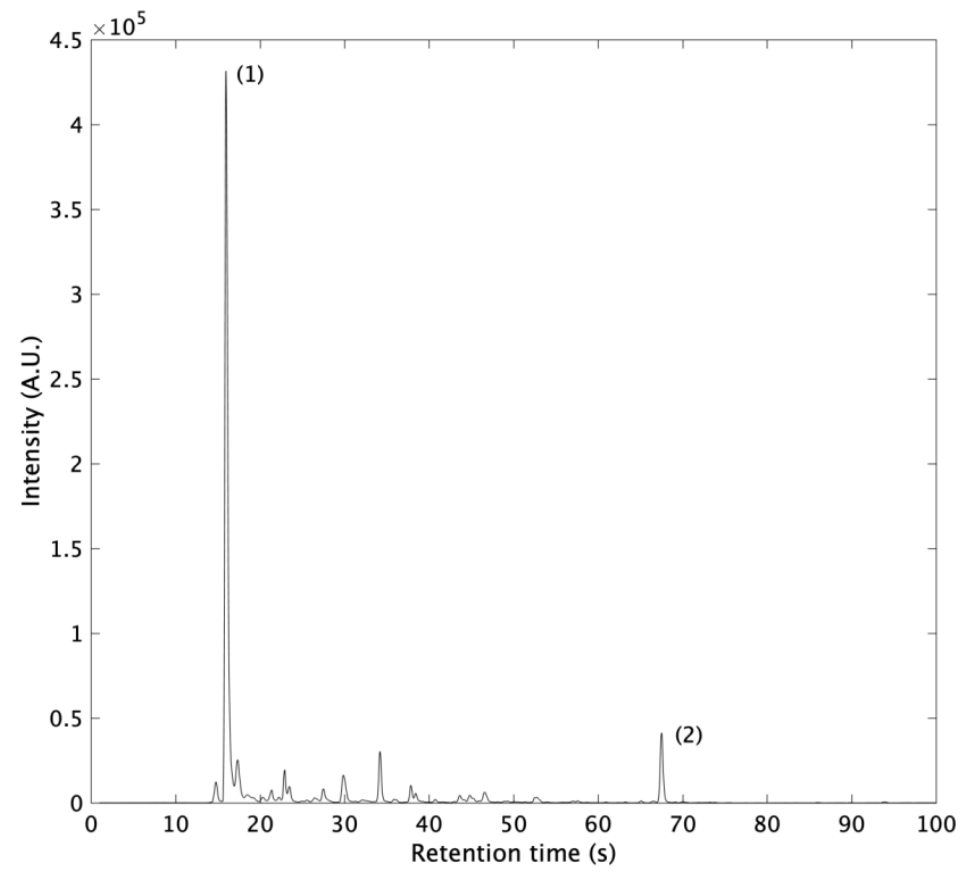

Figure 4. Flash GC chromatogram of olive oil sample belonging to HD2. (1): Ethanol; (2): (E, E)-2,4-decadienal This is backed up by several studies whose results indicate the presence of (E, E)-2,4-decadienal in seed oil after applying heat (Andrikopoulos et al., 2004; Boskou et al., 2006). 


\section{Conclusion}

The harvest date appears to have a decisive role in the qualitative characteristics, saponifiable and non-saponifiable fraction of Lebanese olive oil. All results obtained showed that the harvest date strongly influenced acidity and total polyphenols. Besides, a change in the fatty acid profile characterized by a higher linoleic and lower oleic content, an increase in $\Delta^{7}$-stigmastenol exceeding the limit set by the IOC standards, and a dominating aromatic compound (ethanol) was noticed for olive fruits picked at a later date

Generally, it can be concluded that the harvest from mid-October to the first of November could be a criterion to obtain olive oil of the highest quality grade. Harvesting at this period is preferred for the Soury variety, as it ripens most of the macro and minor components exceed the limits set by the international olive council for extra virgin olive oil. Nonetheless, palmitic acid was the only compound to exceed the limit regardless of the harvest date, and further investigations are required to determine the possible cause of such high content.

\section{Acknowledgments}

The authors would like to acknowledge the Lebanese University [504/12/CU] and the National Council for Scientific Research of Lebanon [5/2106] for their financial support and for granting a doctoral fellowship to "Omar Dib." All authors contributed equally to experiment conception, conduction, data analysis, manuscript writing, and final correction.

\section{References}

Alowaiesh, B., Singh, Z., \& Kailis, S. (2016). Harvesting time influences fruit removal force, moisture, oil content, free fatty acids and peroxide in the oil of Frantoio and Manzanilla olive cultivars. Australian Journal of Crop Science, 10, 1662-1668. http://doi.org/10.21475/ajcs.2016.10.12.p7737

Amiot, M. J., Fleuriet, A., \& Macheix, J. J. (1986). Caractérisation des produits de dégradation de l'oleuropein (Technological debittering process of olives: characterization of fruits before and during alkaline treatment). Groupe Phenolic, 364-369.

Amiot, M. J., Tacchini, M., Fleuriet, A., \& Macheix, J. J. (1990). Le processus téchnologique de désamérization des olives: caractérisation des fruits avant et pendant le traitement alcalin. Sci. Alim, 10, 619-631.

Amira, E. A., Behija, S. E., Beligh, M., Lamia, L., Manel, I., Mohamed, H., \& Lotfi, A. (2012). Effects of the ripening stage on phenolic profile, phytochemical composition and antioxidant activity of date palm fruit. $J$ Agric Food Chem, 60(44), 10896-10902. http://doi.org/10.1021/jf302602v

Anastasopoulos, E., Kalogeropoulos, N., Kaliora, A., Kountouri, A., \& Andrikopoulos, N. (2011). Quality indices, polyphenols, terpenic acids, squalene, fatty acid profile, and sterols in virgin olive oil produced by organic versus non-organic cultivation method. Food and Environment, 152, 135-143. http://doi.org/10.2495/FENV110141

Andrikopoulos, N., Chiou, A., Mylona, A., Boskou, G., \& Dedoussis, G. (2004). Monitoring of 2,4-decadienal in oils and fats used for frying in restaurants in Athens, Greece. European Journal of Lipid Science and Technology, 106, 671-679. http://doi.org/10.1002/ejlt.200401001

Aparicio, R., \& Morales, M. T. (1998). Characterization of Olive Ripeness by Green Aroma Compounds of Virgin Olive Oil. Journal of Agricultural and Food Chemistry, 46(3), 1116-1122. http://doi.org/10.1021/jf970540o

Beayno, F., Mattar, C., \& Abdul-Nour, H. (2002). Mgharet al-Houriye (Karm Sadde, caza de Zgharta): rapport Pré liminaire de la fouille de 2001. Bull Arché ol Archit Liban, 6, 135-178.

Beltrán, G., Bejaoui, M. A., Jimenez, A., \& Sanchez-Ortiz, A. (2015). Ethanol in Olive Fruit. Changes during Ripening. Journal of Agricultural and Food Chemistry, 63(22), 5309-5312. http://doi.org/10.1021/acs.jafc.5b01453

Ben Mansour, A., Chtourou, F., Khbou, W., Flamini, G., \& Bouaziz, M. (2017). Phenolic and volatile compounds of Neb Jmel olive oil cultivar according to their geographical origin using chemometrics. European Food Research and Technology, 243(3), 403-418. http://doi.org/10.1007/s00217-016-2754-5

Bengana, M., Bakhouche, A., Lozano-Sánchez, J., Amir, Y., Youyou, A., Segura-Carretero, A., \& Fernández-Gutiérrez, A. (2013). Influence of olive ripeness on chemical properties and phenolic composition of Chemlal extra-virgin olive oil. Food Research International, 54(2), 1868-1875. https://doi.org/10.1016/j.foodres.2013.08.037

Boskou, G., Salta, F., Chiou, A., Troullidou, E., \& Andrikopoulos, N. (2006). Content of trans,trans-2,4- 
decadienal in deep-fried and pan-fried potatoes. European Journal of Lipid Science and Technology, 108, 109-115. http://doi.org/10.1002/ejlt.200500236

Brkić Bubola, K., Koprivnjak, O., \& Sladonja, B. (2012). Influence of filtration on volatile compounds and sensory profile of virgin olive oils. Food Chemistry, 132(1), 98-103. https://doi.org/10.1016/j.foodchem.2011.10.038

Camera, L., Angerosa, F., \& Cucurachi, A. (1975). L'evoluzione della frazione sterolica dell'olio con il procedere della maturazione delle oliv. Estratto Dagli Annali Dell'lnstituto Sperimentale per la Elaiotecnia Pescara, 5, 3-36.

Cordella, C. B. Y., \& Bertrand, D. (2013). SAISIR: a new general chemometric toolbox. TrAC Trends in Analytical Chemistry, 54. http://doi.org/10.1016/j.trac.2013.10.009

Dag, A., Kerem, Z., Yogev, N., Zipori, I., Lavee, S., \& Ben-David, E. (2011). Influence of time of harvest and maturity index on olive oil yield and quality. Scientia Horticulturae, 127(3), 358-366. https://doi.org/10.1016/j.scienta.2010.11.008

De La Torre, M. C., Lopez, M. C., \& Coleil, J. (1985). Evolución de la fracción esterólica durante la maduración de las aceitunas. Grasas y Aceites, 36(3), 198-202.

EEC. (2013). Implementing Regulation No 1348/2013 amending Regulation (EEC) No 2568/91 on the characteristics of olive oil and olive-residue oil and on the relevant methods of analysis. Official Journal of the European Union. p. 31-67.

El Antari, A., Hilal, A., Boulouha, B., \& El Moudni, A. (2000). Etude de l'influence de la variété, de l'environnement et des techniques culturales sur les caractéristiques des fruits et la composition chimique de l'huile d'olive vierge extra au Maroc. Olivae.

El Qarnifa, S., El Antari, A., \& Hafidi, A. (2019). Effect of Maturity and Environmental Conditions on Chemical Composition of Olive Oils of Introduced Cultivars in Morocco. Journal of Food Quality. https://doi.org/10.1155/2019/1854539

Essiari, M., Zouhair, R., \& H, C. (2014). Contribution to the study of the typical characteristics of the virgin olive oils produced in the region of Sais (Morocco). Off J Int Olive Counc, 119, 8-21.

Famiani, F., Proietti, P., Farinelli, D., \& Tombesi, A. (2002). Oil quality in relation to olive ripening. International Society for Horticultural Science (ISHS). Leuven, Belgium.

Fernández-Cuesta, A., León, L., Velasco, L., \& De la Rosa, R. (2013). Changes in squalene and sterols associated with olive maturation. Food Research International, 54(2), 1885-1889. https://doi.org/10.1016/j.foodres.2013.07.049

Fiorino, P., \& Nizzi, F. (1991). Maturation des olives et variations de certains composants de l'huile. Olivae, 35, 25-33.

Fuentes de Mendoza, M., De Miguel Gordillo, C., Expóxito, J. M., Casas, J. S., Cano, M. M., Vertedor, D. M., \& Baltasar, M. N. F. (2013). Chemical composition of virgin olive oils according to the ripening in olives. Food Chemistry, 141(3), 2575-2581. https://doi.org/10.1016/j.foodchem.2013.05.074

García, J. M., Seller, S., \& Pérez-Camino, M. C. (1996). Influence of Fruit Ripening on Olive Oil Quality. Journal of Agricultural and Food Chemistry, 44(11), 3516-3520. http://doi.org/10.1021/jf950585u

Gargouri, O. D., Rouina, Y. B., Mansour, A. B., Flamini, G., Rouina, B. B., \& Bouaziz, M. (2016). Comparative Study of Oil Quality and Aroma Profiles from Tunisian Olive Cultivars Growing in Saharian Oasis Using Chemometric Analysis. J Oleo Sci, 65(12), 1033-1044. http://doi.org/10.5650/jos.ess15286

Gomez, G., Ruiz, J., \& Luque de Castro, M. (2011). Oil Content and Fatty Acid Profile of Spanish Cultivars During Olive Fruit Ripening. Journal of the American Oil Chemists' Society, 88(11), 1737-1745. http://doi.org/10.1007/s11746-011-1840-x

Gutiérrez, F., \& Fernández, J. L. (2002). Determinant parameters and components in the storage of virgin olive oil. Prediction of storage time beyond which the oil is no longer of "extra" quality. J Agric Food Chem, 50(3), 571-577. http://doi.org/10.1021/jf0102158

Gutiérrez, F., Jímenez, B., Ruíz, A., \& Albi, M. A. (1999). Effect of Olive Ripeness on the Oxidative Stability of Virgin Olive Oil Extracted from the Varieties Picual and Hojiblanca and on the Different Components Involved. Journal of Agricultural and Food Chemistry, 47(1), 121-127. http://doi.org/10.1021/jf980684i 
Hamidoghli, Y., Jamalizadeh, S., \& Malakroudi, M. (2008). Determination of harvesting time effect on quality and quantity of olive (Olea europea L.) oil in Roudbar regions. J Food Agric Environ, 6. Retrieved from http://world-food.net/download/journals/2008-issue_2/a20.pdf

Hernandez, M. L., Padilla, M. N., Sicardo, M. D., Mancha, M., \& Martinez-Rivas, J. M. (2011). Effect of different environmental stresses on the expression of oleate desaturase genes and fatty acid composition in olive fruit. Phytochemistry, 72(2-3), 178-187. http://doi.org/10.1016/j.phytochem.2010.11.026

IOC. (2013). Determination of the composition and content of sterols and triterpene dialcohols by capillary column gas chromatography. International Olive Coucil. COI/ T.20/ Doc. No 30/Rev.1.

IOC. (2017). Method of Analysis, Determination of fatty acid methyl esters by gas chromatography, International Olive Council. International Olive Coucil. COI/T.20/Doc. No. 33.

IOC. (2018). World olive oil figures. Internation Olive Council. Retrieved from http://www.internationaloliveoil.org/estaticos/view/131-world-olive-oil-figures

Flamini, G., Brahmi, F., Dabbou, S., Hassine, K. B., Taamali, A., Chehab, H., Ellouz, M., Zarrouk, M., \& Hammami, M. (2010). Effect of the growing area conditions on differentiation between Chemlali and Chétoui olive oils. Food Chemistry, 119(1), 220-225. https://doi.org/10.1016/j.foodchem.2009.06.012

Ivanova-Petropulos, V., Mitrev, S., Stafilov, T., Markova, N., Leitner, E., Lankmayr, E., \& Siegmund, B. (2015). Characterisation of traditional Macedonian edible oils by their fatty acid composition and their volatile compounds. Food Research International, 77, 506-514. https://doi.org/10.1016/j.foodres.2015.08.014

JM, G., S, S., \& MC, P.-C. (1996). Influence of fruit ripening on olive oil quality. Agric Food Chem, 44(11), 3516-3520. https://doi.org/10.1021/jf950585u

Kesen, S., Kelebek, H., Sen, K., Ulas, M., \& Selli, S. (2013). GC-MS-olfactometric characterization of the key aroma compounds in Turkish olive oils by application of the aroma extract dilution analysis. Food Research International, 54(2), 1987-1994. https://doi.org/10.1016/j.foodres.2013.09.005

Koutsaftakis, A., Kotsifaki, F., \& Stefanoudaki, E. (1999). Effect of extraction system, stage of ripeness, and kneading temperature on the sterol composition of virgin olive oils. Journal of the American Oil Chemists' Society, 76(12), 1477-1481. http://doi.org/10.1007/s11746-999-0188-y

Koutsaftakis, A., Kotsifakis, F., \& Stefanoudaki, E. (2000). La caractérisation des huiles d'olive vierges extra crétoises obtenues à partir de la variété Koroneiki Influence du site d'origine sur plusieurs paramètres chimiques. Olivae, 81, 20-25.

Lazzez, A., Perri, E., Caravita, M. A., Khlif, M., \& Cossentini, M. (2008). Influence of Olive Maturity Stage and Geographical Origin on Some Minor Components in Virgin Olive Oil of the Chemlali Variety. Journal of Agricultural and Food Chemistry, 56(3), 982-988. http://doi.org/10.1021/jf0722147

Lodolini, E. M., Polverigiani, S., Ali, S., Mutawea, M., Qutub, M., Arabasi, T., Pierini, F., Abed, M., \& Neri, D. (2017). Oil Characteristics of Four Palestinian Olive Varieties. J Oleo Sci, 66(5), 435-441. http://doi.org/10.5650/jos.ess16184

Lukić, M., Lukić, I., Krapac, M., Sladonja, B., \& Piližota, V. (2013). Sterols and triterpene diols in olive oil as indicators of variety and degree of ripening. Food Chem, 136(1), 251-258. http://doi.org/10.1016/j.foodchem.2012.08.005

Maaitah, M., Al-Absi, K., \& Al-Rawashdeh, A. (2009). Oil Quality and Quantity of Three Olive Cultivars as Influenced by Harvesting Date in the Middle and Southern Parts of Jordan. Int. J. Agr. Biol., 11, 266-272

Maga, J. A. (1978). Simple phenol and phenolic compounds in food flavor. CRC Crit Rev Food Sci Nutr, 10(4), 323-372. http://doi.org/10.1080/10408397809527255

Mahfoud, S. (2007). Olive oil: where it all began. Green Gold, the story of Lebanese olive oil. W. F. Beirut, Turning Point.

Mailer, R. J., Ayton, J., \& Graham, K. (2010). The Influence of Growing Region, Cultivar and Harvest Timing on the Diversity of Australian Olive Oil. Journal of the American Oil Chemists' Society, 87(8), 877-884. http://doi.org/10.1007/s11746-010-1608-8

Montedoro, G., Servili, M., Baldioli, M., \& Miniati, E. (1992). Simple and hydrolyzable phenolic compounds in virgin olive oil. 1. Their extraction, separation, and quantitative and semiquantitative evaluation by HPLC. Journal of Agricultural and Food Chemistry, 40(9), 1571-1576. http://doi.org/10.1021/jf00021a019 
Morales, M. T., Luna, G., \& Aparicio, R. (2005). Comparative study of virgin olive oil sensory defects. Food Chemistry, 91(2), 293-301. https://doi.org/10.1016/j.foodchem.2004.06.011

Motilva, M.-J., \& Romero, M.-P. (2010). Olives and Olive Oil in Health and Disease Prevention: The Effect of the Ripening Process of the Olive Fruit on the Chlorophyll and Carotenoid Fractions of Drupes and Virgin Oils. Cambridge: Academic Press. p. 59-68. https://doi.org/10.1016/B978-0-12-374420-3.00007-3.

Nergiz, C., \& Ünal, K. (1991). Determination of phenolic acids in virgin olive oil. Food Chemistry, 39(2), 237-240. https://doi.org/10.1016/0308-8146(91)90164-J

Nielsen, N.-P. V., Carstensen, J. M., \& Smedsgaard, J. (1998). Aligning of single and multiple wavelength chromatographic profiles for chemometric data analysis using correlation optimised warping. Journal of Chromatography A, 805(1), 17-35. https://doi.org/10.1016/S0021-9673(98)00021-1

Noorali, M., Barzegar, M., \& Sahari, M. A. (2014). Sterol and Fatty Acid Compositions of Olive Oil as an Indicator of Cultivar and Growing Area. Journal of the American Oil Chemists' Society, 91(9), 1571-1581. http://doi.org/10.1007/s11746-014-2497-z

Pouliarekou, E., Badeka, A., Tasioula-Margari, M., Kontakos, S., Longobardi, F., \& Kontominas, M. G. (2011). Characterization and classification of Western Greek olive oils according to cultivar and geographical origin based on volatile compounds. Journal of Chromatography A, 1218(42), 7534-7542. https://doi.org/10.1016/j.chroma.2011.07.081

Reiners, J., \& Grosch, W. (1998). Odorants of Virgin Olive Oils with Different Flavor Profiles. Journal of Agricultural and Food Chemistry, 46(7), 2754-2763. http://doi.org/10.1021/jf970940b

Rodríguez, J. C., Gómez, D., Pacetti, D., Núñez, O., Gagliardi, R., Frega, N. G., Ojeda, M. L., Loizz, M. R., Tundis, R., \& Lucci, P. (2016). Effects of the Fruit Ripening Stage on Antioxidant Capacity, Total Phenolics, and Polyphenolic Composition of Crude Palm Oil from Interspecific Hybrid Elaeis oleifera $\mathrm{x}$ Elaeis guineensis. Journal of Agricultural and Food Chemistry, 64(4), 852-859. http://doi.org/10.1021/acs.jafc.5b04990

Salvador, M. D., Aranda, F., \& Fregapane, G. (2001). Influence of fruit ripening on 'Cornicabra' virgin olive oil quality A study of four successive crop seasons. Food Chemistry, 73(1), 45-53. https://doi.org/10.1016/S0308-8146(00)00276-4

Silva, M., Freitas, A. M., Cabrita, M., \& Garcia, R. (2012). Olive Oil: Olive Oil Composition, Volatile Compounds. Rijeka: IntechOpen. p. 18-46. https://doi.org/10.5772/28512

Stefanoudaki, E., Chartzoulakis, K., Koutsaftakis, A., \& Kotsifaki, F. (2001). Effect of drought stress on qualitative characteristics of olive oil of cv Koroneiki. Grasas y Aceites, 52(3-4), 202-206. http://doi.org/10.3989/gya.2001.v52.i3-4.358

Temime, S. B., Manai, H., Methenni, K., Baccouri, B., Abaza, L., Daoud, D., Casas, J. S., Bueno, E. O., \& Zarrouk, M. (2008). Sterolic composition of Chétoui virgin olive oil: Influence of geographical origin. Food Chem, 110(2), 368-374. http://doi.org/10.1016/j.foodchem.2008.02.012

Thalman, J. P. (2000). Tell Arqa. BAAL, 4, 5-74.

Trentacoste, E. R., Banco, A. P., Piccoli, P. N., \& Monasterio, R. P. (2020). Olive oil characterization of cv. 'Arauco' harvested at different times in areas with early frost in Mendoza, Argentina. J Sci Food Agric, 100(3), 953-960. https://doi.org/10.1002/jsfa.10029

Varzakas, T. H., Zakynthinos, G., \& Arapoglou, D. (2010). Fruit ripening in relationship to oil quality and some quality characteristics of the Greek olive cultivar koroneiki. Italian Journal of Food Science: IJFS, 22, 401-407.

Vekiari, S. A., Oreopoulou, V., Kourkoutas, Y., Kamoun, N., Msallem, M., Psimouli, V., \& Arapoglou, D. (2010). Characterization and seasonal variation of the quality of virgin olive oil of the Throumbolia and Koroneiki varieties from southern Greece. Grasas y Aceites, 61(3), 221-231. http://doi.org/10.3989/gya.108709

Yorulmaz, A., Erinc, H., \& Tekin, A. (2013). Changes in Olive and Olive Oil Characteristics During Maturation. Journal of the American Oil Chemists' Society, 90(5), 647-658. http://doi.org/10.1007/s11746-013-2210-7

Youssef, N. B., Zarrouk, W., Carrasco-Pancorbo, A., Ouni, Y., Segura-Carretero, A., Fernández-Gutiérrez, A., Daoud, D., \& Zarrouk, M. (2010). Effect of olive ripeness on chemical properties and phenolic composition of chétoui virgin olive oil. Journal of the Science of Food and Agriculture, 90(2), 199-204.

http://doi.org/10.1002/jsfa.3784 
Zeaiter, M., \& Rutledge, D. (2009). Preprocessing Methods: Comprehensive Chemometrics. Oxford: Elsevier. p. $121-231$.

\section{Copyrights}

Copyright for this article is retained by the author(s), with first publication rights granted to the journal.

This is an open-access article distributed under the terms and conditions of the Creative Commons Attribution license (http://creativecommons.org/licenses/by/4.0/). 